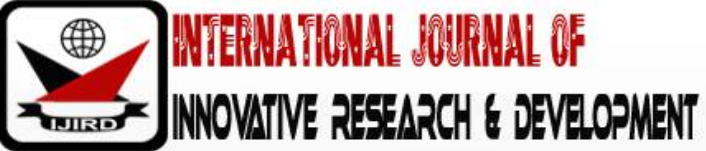

ISSN 2278-0211 (Online)

\section{Transactional Leadership Style and Their Influence on the Learning Motivation and Student's Academic Performance in KCSE Examinations in Migori County, Kenya}

\author{
Dr. James Ochieng Sika
Lecturer, Department of Educational Management and Foundations,
Maseno University, Maseno, Kenya
Peter Ochieng Anyango
Ph.D. Student, Department of Educational Management and Foundations,
Maseno University, Maseno, Kenya
}

\begin{abstract}
:
Effective leadership in a school has been widely noted as a factor that makes a difference between achievers and nonachievers. Majority (50,183 out of 55,272) of the students who sat for (KCSE) between (2011-2015) in Migori County had average marks ( $B$ - and below) which did not guarantee them direct University entry through Kenya Universities and Colleges Central Placement Service. This means that only 5089 made it to the university between (2011-2015), despite the fact that the schools had qualified teachers, adequate resources and facilities to enhance effective learning and good performance. This had caused concern among educational stakeholders in Migori County. What was not known was the Principals' transactional leadership styles and their influence on the learning motivation and students' academic performance. Motivation by the principal for both teachers and students was perceived as imperative in achieving this. The purpose of this study was to investigate the influence of Principals' transactional leadership styles on the learning motivation and students' academic performance in K.C.S.E examinations in Migori County. Douglas McGregor's Theory $X$ and Theory Y guided the study. The study adopted descriptive survey and correlation research designs. The target population was 189 Principals, 3,780 teachers' and 32,710 students in all the secondary schools in Migori County. Stratified random sampling was used to select 127 Principals, 350 teachers and 400 students for the study. The study revealed that there was a positive relationship $(r=.268, p<.05)$ between transactional leadership style and levels of students' performance. This implied that transactional leadership style had some significant influence on learning motivation and student's academic performance in KCSE examination highly qualified principals applied transactional leadership style compared to their less qualified counterparts.
\end{abstract}

Keywords: Transactional, learning motivation, academic performance

\section{Introduction and Background of the study}

Transactional leadership style rests on the reasoning that both authoritarian and democratic management styles need to be mixed in that none can work independently in all situations (Lue \& Byars, 1993).However, Motivation is a psychological feature that arouses an organism to act towards a desired goal and illicit controls, and sustain certain goal directed behaviors. Within the context of Maslow's hierarchy of needs then, transactional leadership styles works at the basic level of need satisfaction, where transactional leaders focus on the lower levels of the hierarchy. Transactional leaders use this model with rewards being for good performance or positive outcomes. Conversely, principals with this leadership style can also punish poor achievement or poor outcomes, until the problem is corrected (Bass, 1985).

The principal who subscribe to this style of leadership is a transactional leader who appreciates the intermediary views of McGregor's Theory X and Theory Y. This is based on the premise that over emphasizing authoritarian management style can subordinate, while too much democracy has a high likelihood of creating anarchy and complacency in an organization (D' Souza, 2008). This style of management has a high likelihood of enhancing academic performance among students. However, studies are silent on Principals transactional leadership styles and their influence on the learning motivation and students' academic performance.

Transactional leadership focuses on monitoring and controlling subordinates (Bass, 1985). It also involves contingent rewards based on the behaviors of subordinate. Transactional leadership encompasses positive exchange of expected performance and rewards between subordinates and leaders (Bono \& Judge, 2004; Bass, 1985). Transactional and transformational are two competing leadership paradigms. Transactional leadership has shown to be effective in achieving short term goals, but transformational leadership is more effective in achieving long term goals (Hautala, 2005). 
Transactional leadership Bass (1985) is as a result of an exchange of relationship between leader and followers. Transactional leadership is grounded in the social exchange theories, which recognize the reciprocal nature of leadership. The transactional leadership process builds upon an exchange whereby the leader offers rewards or threatens punishments for the performance of desired behaviors and the completion of certain tasks (Bass \& Avolio, 1997). According to a study by Bass \& Avolio, (1997), the findings revealed that the attraction of combinative aspects of leadership behavior lies in its simplicity and its apparent effectiveness in improving followers' satisfaction of the leader. However, much more research is needed to further explore this domain of leadership behavior. However, these leadership behaviors provide motivation and support to enable the staff to develop their achievement (Nguyen \& Mohamed, 2011). In the context of Higher Education Institutions, there seems to be a lack of empirical studies that link leadership behavior of the university leaders to achieve performance (Niles, 1997; Nordin, 2011).

According to Karen Seashore Louis, Kenneth Leithwood, Kyla L. Wahlstrom and Stephen E. Anderson et al. (2010), they assert that leadership must be aligned with a collective purpose and effective leaders must be judged by their ability to make social changes. He suggests that the role of the leader and follower be united conceptually and that the process of leadership is the interplay of conflict and power. According to Burns (1978) transactional leaders approach followers with the intent to exchange one thing for another, for example, the leaders may reward the hardworking teacher with an increase in budget allowance. Transactional leadership encompasses a change to benefit both the relationship and the resources of those involved. The result is a change in the level of commitment and the increased capacity for achieving the mutual purposes.

However, Motivation is a psychological feature that arouses an organism to act towards a desired goal and illicit controls, and sustain certain goal directed behaviors. Within the context of Maslow's hierarchy of needs then, transactional leadership styles works at the basic level of need satisfaction, where transactional leaders focus on the lower levels of the hierarchy. Transactional leaders use this model with rewards being for good performance or positive outcomes. Conversely, principals with this leadership style can also punish poor achievement or poor outcomes, until the problem is corrected (Bass, 1985).

In a school setup, principals' with this transactional leadership style can motivate teachers and students by making them work with the help of external motivators such as organizational rewards (Bass, 2000). Studies are silent on the relationship between transactional leadership style and students' academic performance. There is therefore need to investigate the relationship between transactional leadership style on students' learning motivation and students' academic performance. This study sought to fill that gap. In Migori County, poor school performance has persisted despite the fact that schools in the county have adequate and well-trained teachers, fairly well qualified students admitted from primary schools, trained and qualified Principals. The ratio of teachers to students is $1: 3$, out of which $91 \%$ of the teachers are qualified graduate teachers, while $83 \%$ of the students admitted had 250 marks and above in KCPE (Quality Assurance and Standards Office report Migori County 2014). This raised concern among education stakeholders, community and students, sometimes leading to Principals being locked out. The reasons for poor performance consistently over the years cannot easily be discerned without focused investigation. This study was therefore necessary to further investigate points of non-consensus on leadership styles and students' performance in the Kenya Certificate of Secondary Education examination by various scholars and how various leadership styles adopted by Principals influence academic performance. The performance of the students in the county over the last five years is as shown in Table1.

\begin{tabular}{|c|c|c|c|c|c|c|}
\hline \multirow{2}{*}{ S No. } & Name of the County & \multicolumn{5}{|c|}{ Mean Score Per Year Per County } \\
\cline { 3 - 7 } & & 2015 & 2014 & 2013 & 2012 & 2011 \\
\hline 1. & Homabay & 5.5686 & 4.8090 & 4.9809 & 47906 & 4.6531 \\
\hline 2. & Kisii & 4.6071 & 4.6521 & 4.9231 & 4.6021 & 4.6002 \\
\hline 3. & Kisumu & 5.3421 & 4.8823 & 5.4213 & 5.1234 & 5.1471 \\
\hline 4. & Migori & 4.3214 & 4.4123 & 4.8120 & 4.5231 & 4.5312 \\
\hline 5. & Nyamira & 4.5213 & 4.4211 & 4.9231 & 4.6023 & 4.6004 \\
\hline 6. & Siaya & 5.3043 & 4.8800 & 5.3158 & 5.1000 & 5.1426 \\
\hline
\end{tabular}

Table 1:K.C.S.E Performance in Migori County (2011-2015) Source: Regional Director, Nyanza (2014)

The mean score for the county remained below average over the last five years. Though there was marked improvement from 2011, the performance cannot be compared to other Counties which register high quality grades all the years.

\begin{tabular}{|c|c|c|c|c|c|c|}
\hline \multirow{2}{*}{ Year } & \multirow{2}{*}{ Enrolment } & \multicolumn{4}{|c|}{ Mean Grade } & \multirow{2}{*}{ Quality Grades } \\
\cline { 3 - 6 } & & $\mathrm{A}$ & $\mathrm{A}-$ & $\mathrm{B}+$ & $\mathrm{B}$ & \\
\hline 2015 & 13,130 & 35 & 225 & 451 & 523 & 1234 \\
\hline 2014 & 11,452 & 32 & 200 & 350 & 426 & 1008 \\
\hline 2013 & 10,590 & 29 & 199 & 349 & 400 & 977 \\
\hline 2012 & 10,120 & 25 & 180 & 351 & 395 & 951 \\
\hline 2011 & 9,980 & 26 & 178 & 335 & 380 & 919 \\
\hline
\end{tabular}

Table 2: Migori County K.C.S.E Mean Scores and Quality Grades (2011-2015)

Source: Quality Assurance and Standards Office, Migori County (2014) 
From the foregoing, the public have varied reasons for criticizing Principals' who register poor results and they attribute it to poor or ineffective leadership. The Kamunge report (Republic of Kenya 1988) noted that Principals' were appointed from among serving class teachers and are not adequately trained on institutional management. Griffin (1996), argued that the trend of appointing teachers to leadership positions is the major cause of ineffective leadership in secondary schools. This study, therefore, aimed at investigating the principals' transactional leadership styles and their influence on the learning motivation and students' academic performance in K.C.S.E examinations in schools in Migori County. This study sought to fill that gap.

\subsection{Statement of the Problem}

Majority of the students (50183 out of 55272) who sat for K.C.S.E between (2011-2015) in Migori County had average marks (B- and Below). Meaning that only 5089 out of the 55272 students who sat for KCSE in that period, representing $9.21 \%$ made it to the university directly through the Kenya Universities and Colleges Central Placement Service. There were numerous cases of principals being locked out of schools after KCSE results have been released and insome instances, they were rampart cases of some heads being forced to go for transfer or being dropped from leadership positions (QASO Migori 2012). This raises the question of whether the principal transactionalleadership styles influence students' learning motivation and academic performance.

\subsection{The Purpose of the Study}

The purpose of the study was to examine the influence of the Principals Transactional leadership styles on the students' learning motivation and academic performance in KCSE Examinations;

\subsection{Hypotheses of the Study}

The study tested the following null hypothesis

- $\mathrm{HO}_{1}$ : There was no significant influence of the Principals Transactional leadership styles on the learning motivation and students' academic performance in KCSE Examinations?

\section{Theoretical Framework}

The relationship between a leader's attitude towards fellow workers and hence his or her willingness to involve them in organizational affairs is expounded in McGregor's (1960) Theory X \& Theory Y assumptions about human motivation. McGregor's has posited that in Theory X leaders view their co-workers as lazy, self- centered, work avoidant, and indifferent to organizational goals. In contrast theory $\mathrm{Y}$ is grounded on a human management style for it exhibits a positive orientation towards members of an organization. The basic tenet of that theory was that organizational members were honest, industrious, responsible and always willing to take the initiative to better the organization goals. Leaders espousing Theory Y attitude towards field workers were therefore more inclined to delegate, share responsibility and enable co-workers participate in making various organizational decisions (Copland, 2003).

\section{Research Design and Methodology}

\subsection{Research Methodology}

The study adopted descriptive survey design and correlation research design. Fraenkel and Wallen (2014) define survey as that method that involves asking a large group of people questions about a particular issue. Information will be obtained from a sample rather than the entire population at one point in time. The researcher will use descriptive survey design for this study because it allows for generalization from a sample to a population so that inferences can be made about some characteristic, attitudes or behaviour of the population (Babbie, 1990).

\subsection{Area of Study}

The study was carried out in Migori County. The county comprises seven sub counties including Rongo, Uriri, Migori, Awendo, Nyatike, Kuria East and Kuria West Sub Counties. It is situated in the south western part of Kenya. It borders Homa-bay county to the North, Kisii and Narok Counties to the East and the Republic of Tanzania to the South. It also borders Lake Victoria to the West. The county is located between latitude 0 o 4024 South and 0 o 40 South and Longitude $34^{\circ}$ East and $34^{\circ} 50$ East and covers an area of $2,596.5 \mathrm{Km}^{2}$ including approximately $478 \mathrm{Km}^{2}$ of water surface.

\subsection{Target Population}

The target population comprised Principals, teachers and students of secondary schools in Migori County. The study targeted 189 Principals out of whom 114 were male while 75 were female, 3,780 teachers, out of whom 2,520 were male while 1,260 were female and 32,710 students, out of whom 17,808 were boys while 14,902 were girls.

\subsection{Sampling Techniques and Research Instruments}

In this study, the research used purposive and stratified random sampling. Two research instruments were used to collect data namely: The researcher found the questionnaire adequate for the study because it minimized bias on the side of the researcher and the respondents (Kombo \& Tromp, 2006).According to Mugenda and Mugenda (1999), in depth interview provides data that is not possible to obtain using questionnaire. They further observe that it is possible for the interview to clarify questions that were not clear in the interview schedule. Probing was therefore be used where the responses were not clear during interview. 


\section{Results and Findings}

\subsection{Introduction}

This section presents summarized results of learning Motivation and student academic performance according to respondents views and then deals with transactional leadership style and their influence on learning motivation and student academic performance from which results are presented.

\subsection{Learning Motivation and Student's Academic Performance}

\begin{tabular}{|c|c|c|c|c|c|c|c|}
\hline $\begin{array}{c}\text { Statement } \\
\end{array}$ & SA f (\%) & Af (\%) & U f (\%) & D f (\%) & SD f (\%) & Mean & STD \\
\hline $\begin{array}{l}\text { Are you involved in rating students' } \\
\text { performance? }\end{array}$ & $147(31.2)$ & $205(43.3)$ & $43(9.2)$ & $47(10.3)$ & $28(5.9)$ & 2.16 & 1.15 \\
\hline $\begin{array}{c}\text { Students perform well in CATS and } \\
\text { other tests. }\end{array}$ & $96(27.6)$ & $163(46.6)$ & $45(13.1)$ & $35(10.1)$ & $8(2.5)$ & 2.13 & .98 \\
\hline $\begin{array}{l}\text { Intelligence is related to students } \\
\text { performance }\end{array}$ & $126(26.6)$ & $228(47.9)$ & $68(14.4)$ & $41(8.7)$ & $11(2.5)$ & 2.13 & 1.04 \\
\hline $\begin{array}{l}\text { Students' academic performance is } \\
\text { dependent on the leadership styles }\end{array}$ & $260(29.6)$ & $391(44.6)$ & $133(15.2)$ & $71(8.1)$ & $22(2.5)$ & 2.09 & .99 \\
\hline Students actively participate in class & $107(30.6)$ & $155(44.5)$ & $49(14.0)$ & $30(8.7)$ & $8(2.3)$ & 2.08 & .99 \\
\hline $\begin{array}{l}\text { Staff motivation is related to good } \\
\text { performance }\end{array}$ & $420(47.9)$ & 293(33.4) & $80(9.1)$ & $42(4.8)$ & $42(4.8)$ & 2.00 & 1.08 \\
\hline Overall mean & & & & & & 2.07 & 0.57 \\
\hline
\end{tabular}

Table 3: Respondents view on Learning Motivation and Students Academic Performance

Table 3 results indicate that there was a slightly high academic performance of students in school as highly rated by $43.3 \%$ of the respondents, who also observed that students performed well in CATS and other tests as shown by high percentage of $46.6 \%$ and low mean rate of 2.13 implying that they agreed. There was also a relationship between intelligence and academic performance according to the views rating with $47.9 \%$ in agreement and a mean of 2.13 . Respondents also agreed that students academic performance was dependent on the leadership styles, (44.6\%, STD=2.09), and that students actively participated in class $(44.5 \%$, STD $=2.08)$. respondents also agreed that staff motivation is related to good performance, $(47.9 \%, \mathrm{STD}=1.85)$. In general, it was established that learning motivation and student's academic performance were influenced by leadership styles as reflected by an overall mean of 2.07 and standard deviation of 0.57 indicating low variability in the response.

\section{Transactional Leadership Style on Learning Motivation and Student's Academic Performance}

The study sought to establish the extent of adoption of transactional leadership style on learning motivation and student's academic performance. It was investigated by use of a pre-designed questionnaire tailored to collect the views of the school principals, teachers and students. A five point Linkert-scale was also used in this case, starting from strongly agree, agree, undecided, disagree, strongly disagree order. The descriptive statistics are presented as shown in table 4.

\begin{tabular}{|c|c|c|c|c|c|c|c|}
\hline Statement & SA f (\%) & Af (\%) & U f (\%) & D f (\%) & SD f (\%) & Mean & STD \\
\hline $\begin{array}{c}\text { Teachers are involved in } \\
\text { designing academic programs in } \\
\text { the school (all). }\end{array}$ & $308(35.1)$ & $389(44.4)$ & $72(8.2)$ & $66(7.5)$ & $42(4.8)$ & 2.03 & 1.08 \\
\hline $\begin{array}{c}\text { Academic leadership roles are } \\
\text { shared by teaching staff (all) }\end{array}$ & $283(32.3)$ & $425(48.5)$ & $94(10.7)$ & $61(7.0)$ & $14(1.6)$ & 1.97 & .92 \\
\hline $\begin{array}{c}\text { Delegation of powers to the } \\
\text { subordinate staff strongly exists } \\
\text { (all). }\end{array}$ & $158(18.0)$ & $357(40.7)$ & $157(17.9)$ & $131(14.9)$ & $74(8.4)$ & 2.55 & 1.90 \\
\hline $\begin{array}{c}\text { What is important in school } \\
\text { management is accomplishment } \\
\text { of tasks (all). }\end{array}$ & $140(16.0)$ & $236(26.9)$ & $155(17.7)$ & $210(23.9)$ & $136(15.5)$ & 2.96 & 1.33 \\
\hline $\begin{array}{c}\text { Academic decisions are } \\
\text { centralized in the principal (all). }\end{array}$ & $267(30.4)$ & $254(29.0)$ & $121(13.8)$ & $164(18.7)$ & $71(8.1)$ & 2.45 & 1.31 \\
\hline $\begin{array}{c}\text { The system of administration is } \\
\text { top down (all). }\end{array}$ & $279(31.8)$ & $274(31.2)$ & $101(11.5)$ & $121(13.8)$ & $102(11.6)$ & 2.42 & 1.36 \\
\hline Overall mean & & & & & 2.39 & 0.57 \\
\hline
\end{tabular}

Table 4: Respondents view on Transactional Leadership Style

Table 4 results indicate that teachers are involved in designing academic programmes in school as strongly agreed by $35.1 \%$ and agreed by $44.4 \%$ of the respondents, making a cumulative $79.5 \%$ agreement on the statement. This implies that as one of the aspects of transactional leadershi0p style, teacher's involvement in designing academic programmes is 
practices in schools as affirmed by a mean of 2.03 with small variations in the views (STD=1.080. On the second aspect; academic leadership roles sharing by the teaching staff, the response on agreement was overwhelming with $48.5 \%$ lead. A mean score of 1.97 and small standard deviation of .92. which was below one standard deviation, confirmed that the aspect was largely practiced with very small variation. Delegation of power to the subordinate staff we also observed as agreed by $40.7 \%$ of the respondents, with a cumulative percentage of $58.7 \%$ of the respondents in agreement. A mean of 2.55 and standard deviation of 1.18 indicated that even though this was practiced, there was variation in the views on the same. Majority of the respondent's percentage, $26.9 \%$ also perceived that what is important in school management is accomplishment of task at hand and not addressing staff needs. However, $23.9 \%$ of the respondents, which was second largest, disagreed on the same statement, but a mean of 2.96 slightly below the neutral value of 3.0 confirmed positive results, accompanied by large variation in the response (STD=1.33). All power concerning academic decisions was also perceived to be centralized in the principals and indicated by a mean of 2.45 and the highest percentage (30.4\%) of the respondents agreeing on the same, and finally, highest percentage $(31.8 \%)$ of respondents observed that there was a top down system of administration. An overall mean of 2.39 and standard deviation of .57 confirmed that the overall rating on the practice of transactional leadership style in the schools was high.

\subsection{Hypothesis Testing: The Relationship between Transactional Leadership Style and Student's Learning Motivation \& Academic Performance}

To answer the third research, the researcher tested the hypothesis, 'there is no significant relationship between transactional leadership style and student's learning motivation \& Academic performance.' To investigate this relationship an inferential statistic, correlation coefficient was computed using the bivariate correlation analysis. The independent variable used was the scores from the views of respondents on transactional leadership style' questionnaire; while dependent variable was the learning motivation and student's academic performance in KCSE examinations scores also generated from the views the respondents. After conducting the necessary preliminary analyses to ensure suitability of data, the Pearson Product-Moment correlation co-efficient analysis was conducted. Results are presented in table 5

\begin{tabular}{|c|c|c|c|}
\hline & & $\begin{array}{c}\text { New Overall } \\
\text { Performance }\end{array}$ & $\begin{array}{c}\text { New Transactional } \\
\text { Leadership Styles }\end{array}$ \\
\hline & Pearson Correlation & 1 & $.268^{* *}$ \\
\hline New overall performance & Sig (2-tailed) & & .000 \\
\hline & $\mathrm{N}$ & 877 & 877 \\
\hline New transactional leadership styles & Pearson Correlation & $.268^{* *}$ & 1 \\
\hline & Sig (2-tailed) & .000 & 877 \\
\hline
\end{tabular}

Table 5: Correlation between Transactional Leadership Style and Learning

Motivation and Students Academic Performance in KCSE

${ }^{* *}$ Correlation is significant at the 0.01 level (2-tailed)

From the findings in table 5, there was a low positive significant correlation between transactional leadership style, and learning motivation and student's academic performance (r-.268,p<.05). This implied that transactional leadership style had some significant influence on learning motivation and student's academic performance in KCSE examination. This kind of association, though significant, was however classified as low due to the very low coefficient of correlation, and therefore necessary to carry out a partial correlation. The partial correlation was meant to find out whether extraneous variables contributed to the low association between the perceived independent and dependent variable. The result for partial correlation are presented below:

\begin{tabular}{|c|c|c|c|c|}
\hline Control Variables & & $\begin{array}{c}\text { Overall } \\
\text { Performance }\end{array}$ & $\begin{array}{c}\text { New Transactional } \\
\text { Leadership Styles }\end{array}$ \\
\hline & performance & $\begin{array}{c}\text { Cignificance }(2- \\
\text { tailed) }\end{array}$ & $\cdot .000$ & .232 \\
\hline & & Df & 0 & .000 \\
\hline Extraneous Variables & & Correlation & .232 & 874 \\
\hline & $\begin{array}{c}\text { New transactional } \\
\text { leadership styles }\end{array}$ & $\begin{array}{c}\text { Significance }(2- \\
\text { tailed) }\end{array}$ & .000 & 1.000 \\
\hline & & Df & 874 & $\cdot$ \\
\hline
\end{tabular}

Table 6: Partial Correlation between Transactional Leadership Styles and Learning Motivation and Student's Academic Performance

Table 6 correlation results indicate that despite the control of extraneous variables, there was still a low positive significant correlation between transactional leadership style, and learning motivation and student's academic performance, and in fact, with further reduction in the association between the two variables $(\mathrm{r}=.232, \mathrm{p}<.05)$. This implies that extraneous variables did not have a significance therefore led to the rejection of the null hypothesis; hence the study concluded that there was significant positive relationship between transactional leadership style, and learning motivation 
and student's academic performance. A coefficient of determination, calculated from the coefficient of correlation of $\mathrm{r}=.268$ in table 4.12 , was established to be 0.07182 . This finding implies that perceived transactional leadership style accounted for about 7.2 percent (when rounded off to two decimal places) of the variance in respondents' scores on the learning motivation and academic performance in KCSE exams. This was also a small amount of variance explained by a single independent variable of interest in the study.

\section{Conclusion}

The findings revealed that there was a small relationship between transactional leadership style and students' learning motivation and academic performance. The study therefore concluded that transactional leadership style could contribute much to other areas of leadership in schools but not to performance and learning motivation.

\section{Recommendations}

School heads and managers should undergo thorough training in transactional leadership styles so as to align their mode of leadership with performance

\section{References}

i. Babbie, E. (1990). Survey research methods (2nd ed.). Belmont, CA: Wadsworth.

ii. Bass, B. M. (2000). The future of leadership in learning organizations: Journal of Leadership Studies, 7 (3) 18-40.

iii. Bass, B. M. (1990). Handbook of leadership: Theory research and managerial application. New York: Free press

iv. Bass, B. M. (1985) Leadership and performance beyond expectations: York: Free press

v. Burns, J.M. (1978). Leadership. New York, Harper Collins.

vi. D'souza, A. (2006). A Trilogy on Leadership and effective management. Nairobi: Pauline's Publication Kolbe Press.

vii. D'souza, A. (2008). Leadership. Nairobi: Paulines Publishers Africa.

viii. Fraenkel, J. R., \& Wallen, N.E. (2014). How to design and evauate research in education. New York: McGraw-Hill.

ix. Karugu, A. M, (1982), Primary School Teachers in Kenya: A study of Teachers Views on Promotion, Nairobi: Bureau of Educational Research, K.U.

X. Kombo, D.K., \& Tromp, A. (2006). Proposal and thesis writing. Makuyu: Dno Bosco Printing Press.

xi. Mugenda, Olive M., \& Abel G.M. (1999). Research Methods: Quantitative and Qualitative Approaches Nairobi, Kenya: Acts Press pg. 45, 72, 97. 